\title{
Labor conflicts in the Spanish press: strikes as a reflection of the contradiction between capital and labor
}

\author{
Iván Carretero-Navarro \\ Eva Espinar-Ruiz (University of Alicante)
}

\begin{abstract}
A qualitative content analysis has been applied to a sample of news related to labor strikes from three major newspapers in Spain. Results suggest that news media mainly focus on the immediate negative consequences of the strikes rather than on causes and further explanations. Strikes are portrayed as isolated occurrences that happen because of disagreements between specific companies and workers. The attention is put on events (demonstrations, disorders, economic losses, etc.) and not on the structural causes of the strikes: the contradiction between capital and labor and the consequent tension among social classes. Within this frame, strikers and their organizations are delegitimized and isolated from the rest of the society. News media readers are categorized as consumers, and their interests are depicted as alien or even opposed to those of striking workers.
\end{abstract}

Keywords: labor strikes, news media, qualitative analysis, capitalism, Marxist ideology critique

Resumen: En esta investigación se ha aplicado un análisis de contenido cualitativo a una muestra de noticias relacionadas con huelgas laborales procedentes de tres de los principales periódicos españoles. Los resultados sugieren que la prensa se centra, principalmente, en informar sobre las consecuencias negativas e inmediatas de las huelgas, en lugar de explicar las causas u otros datos adicionales. Las huelgas se describen, así, como sucesos aislados, que ocurren debido a desacuerdos específicos entre empresas y trabajadores. La atención se focaliza en los eventos (manifestaciones, desórdenes, pérdidas económicas, etc.) y no en las causas estructurales de las huelgas: la contradicción entre capital y trabajo y la consiguiente tensión entre las clases sociales. En este marco, los huelguistas y sus organizaciones son deslegitimados y aparecen aislados respecto del resto de la sociedad. La prensa sitúa a sus lectores dentro del colectivo de consumidores, cuyos intereses se representan como ajenos o incluso contrarios a los de los trabajadores en huelga.

Palabras clave: huelgas laborales, medios informativos, análisis cualitativo, capitalismo, crítica marxista de la ideología. 


\section{Introduction}

Private ownership of the means of production requires labor power. This is one of the pillars of capitalism. Men and women from the producer class sell their labor power to the owners of the means of production in exchange for a salary. Thus, employers see workers as instruments of production that must give their maximum contribution at the minimum cost (Marx, 1932/1984). The global economy has changed since the nineteenth century. Now there are other productive structures, the move from Fordism to post-Fordism, flexibility in production, the greater weight of immaterial and intellectual labor, financial economies and neoliberalism as the hegemonic ideology. These changes have resulted in a more complex reality, but they have not replaced the fundamental contradiction between labor and capital. In fact, in this article we assume that labor strikes are a reflection of the persistence of this contradiction, whose place within the collective imaginary requires to be studied.

Social discourses about strikes, workers and their organizations, and labor conflicts in general, can be fundamental to understanding the widespread decrease in social support for unions and in their political influence, or even to understanding the current tendency towards a precarious and deregulated labor market (Roca and Sánchez, 2017). The maintenance of any relationship of domination requires a legitimizing discourse that takes shape within specific social structures (van Dijk, 2002). Old and new media are critical tools in the communication practices that work together to configure hegemonic discourses and definitions of normative social reality. Accordingly, the general objective of this article is to characterize how mainstream news media portray labor strikes, which we consider to be reflections of the systemic contradiction between labor and capital.

The next section summarizes our theoretical perspective, which is based on Marxist approaches to mass media and cultural studies. Then, in describing the state of the art, we introduce the few existing studies related to the media representation of strikes, and we frame the research within the wider field of social protest representations. The methodology section explains the process of selection, collection and analysis of the data. After presenting the results, they are discussed in relation to the literature review and previously existing research.

\section{Marxist media analysis and cultural studies}

Marxist Political Economy affirms that media are essentially a tool of the capitalist system and function to transmit and maintain the dominant ideology. According to Wright Mills (1960), media owners and power elites use these platforms for modeling people's identities, aspirations and global visions. This would be one of the most important functions of the media: "the function of domination" (Holzer, 2017). Marx and Engels, in The German Ideology (1846/1970, p. 64), summarize the process in the following words:

The ideas of the ruling class are in every epoch the ruling ideas, i.e. the class which is the ruling material force of society is at the same time its ruling intellectual force. The class which has the means of material production at its disposal has control at the same time over the means of mental production.

A key concept in the struggle to control the making of meanings is hegemony. According to Gramsci, hegemony is the cultural domination that the ruling class exerts over the other social classes and prevents or directs social change. It is a subtle social and cultural scheme that makes possible the subordination of the non-ruling to the ruling classes in liberal democracies. Manufacturing of "common sense" is central (Donoghue, 2017) to the exercise of hegemony 
and the configuration of an intellectual and moral unity (Gramsci, 1971): i.e. "a whole body of practices and expectations, over the whole of living; our senses and assignments of energy, our shaping perceptions of ourselves and our world" (Williams, 1977, p. 110).

Following this logic, Althusser insisted on the importance of subjective subordination (the mystification and distortion of daily life by state ideological apparatus) as compared to objective subordination (economic, structural) (Corner, 2011). He uses the term "interpellation" to explain the way in which agents of socialization, among them the mass media, provide an identity to the audience, such that they can negotiate their own reality and position themselves socially (Farooq, 2015). Thus, Althusser situates the problem of interpellation at the center of the critical analysis of ideology, as a key concept to explain "how we come to speak 'spontaneously' within the limits of the categories of thought which exist outside us and which can more accurately be said to think us" (Hall, 1983, p. 32).

The theories of Gramsci and Althusser have been reconfigured within the Marxist tradition of Cultural Studies, in order to analyze the relationship between culture (i.e. the production of meanings), economics and politics. This tradition assumes that it is within the cultural sphere that inequality (of class, gender, race and others) is "naturalized and represented in forms that sever (as much as possible) the connection between [it] and economic and political inequalities" (O'Sullivan et al. 1994, p. 71). Stuart Hall (1997), one of the most influential authors in Cultural Studies, assigns culture the role of regulating conduct through at least three processes: normativity (shared values and meanings that permit comprehension of our behavior by others); classification (indicating the limits between what is accepted and what is not); and the production of subjects (which defines what class of subjects we are). Specifically, mass media are a fundamental instrument in the "critical ideological work of constructing [shared meanings and] a populist common sense" (Hall, 1983, p. 29). In fact, "the mobilization of consent [is] a matter of discourse" (Wood, 1998). Although Hall recognizes the possibility of a certain plurality in this discourse, he insists that it is a limited plurality, since ideologies cannot "proceed free of or outside the structuring lines of force of power and class" (Hall 1988, p. 45). Consequently, "it is not just that hegemony partially fixes the meaning of the social, but also the other way round: the social patterns hegemonic meaning" (Wood 1998, p. 405)

Hall uses the term "articulation" to explain the relationship between social forces and the dominant discourse. This relationship is neither necessary nor absolute and is developed under concrete historical conditions (Slack, 1996). Thus, belonging to a social class does not necessarily lead to a discourse based on corresponding interests. Hall describes two moments of articulation: 1) the formation of a dominant block between different interests, and 2) the articulation of the discourse with sub-alternate classes through concessions allowing them to identify with the dominant block (Clarke, 2015). Along these lines, Laclau relates hegemony and articulation in proposing that a class will be hegemonic if it manages to articulate in its own discourse non contradictory elements of the other classes, eliminating the transformative potential of antagonistic positions (Slack, 1996). In this way, it is possible to articulate a populist discourse that constructs a political subject (the people), that is contingent and heterogeneous. The constitution of this political subject results in two antagonistic identities (one's own side and the enemy), not determined previously by social class (López, 2014). It is therefore a process of articulation in which both transformative projects and those that reinforce the status quo compete for hegemony. 


\section{Labor Conflicts in Mass Media}

There is wide theoretical and empirical production regarding the analysis of how mass media portray social movements and different forms of collective protest (McCurdy, 2012). However, there is less research on the specific treatment of labor movement and organizations. Existing studies have applied qualitative (Coscia, 2009; Kumar, 2001; Martin, 2004; Morley, 1976; Parenti, 1993; Puette 1992; Tracy, 2004) or quantitative (Brimeyer et al. 2016; Bruno 2009; Cárdenas, 2014; Harmon and Lee, 2010; Oshagan and Martin, 1999; Roca and Sánchez, 2017; Wright; 2001) methods. Quantitative studies conclude that most of the information related to labor issues centers on strikes (Harmon and Lee, 2010). Other aspects of labor organization and unions are not likely to attract media attention (Erickson and Mitchell, 1996; Goldman and Rajagopal, 1991). As a result, unions' work is not accurately represented and their media references are identified with "bad news" (Thomas 2012, p. 61), conflict and disorder (McChesney, 1999).

In general, media situate labor news within a frame characterized by an anti-union bias (Brimeyer et al., 2016; Bruno, 2009; Harmon and Lee, 2010; Oshagan and Martin, 1999). The concept of frame is widely used in media analysis. According to Entman (1993, p. 52), framing is the process of selecting "some aspects of a perceived reality and make them more salient (...), in such a way as to promote a particular problem definition, causal interpretation, moral evaluation, and/or treatment recommendation for the item described". As a consequence, framing processes emphasize certain dimensions and features of an issue while lessening or ignoring others (Brimeyer et al., 2016). Media framing of labor is normally characterized by an emphasis on concrete strikes, their consequences and damage. This is a frame that makes it impossible to really understand the reasons behind the mobilizations (Cardenas, 2014). Nonimmediate causes are excluded from the discourse, "rarely offering any analysis of the relationship between particular events and underlying structural processes" (Morley 1976, p. 206). In her analysis of two labor strikes in Argentina, Coscia (2009) emphasizes the frame of public altercation that dominates the information on strikes. As a result, strikers, activists and trade unions are represented as a problem for society (Wright, 2001; Walsh, 1988; Thomas, 2012) and their acts of protest are delegitimized (Bruno, 2009; Morley, 1976).

This media representation of labor conflicts can be related to different causes. For example, Carreiro (2005) argues that media recount news from the consumer perspective, narrated in terms of consumers' interests. Thus, for example, there is a tendency to give voice to users affected by the paralysis of public and private services (Coscia, 2009). Authors also stress the intimate relationship between media and economic and political elites, if only because of their dependence on advertisers. This reasoning leads Carreiro (2005) to conclude that labor strikes, as class movements, maintain a particularly conflictive relationship with the media. Wright (2001, p. 185) uses the term "ties to the elites" to explain how the media manage nonconformity in capitalism by representing unions as extremists. In this respect, media tends to leave unquestioned the structural tensions within labor-capital relationship (Thomas, 2012)

Much of the research on general social protest identifies similar media support for the status quo. In fact, the so called "protest paradigm" has described the media coverage of protests as based on the de-legitimization or marginalization of the groups that defy power, and as focused on manifestations and violence, not on causes (McLeod and Detenber, 1999). This creates a narrative centered on specific episodes of conflict, especially between activists and police. The idea of the lack of support of public opinion is transmitted, and the protagonists of the protests are labeled as extremists and radicals. The information usually comes from official sources and rarely from social movement's sources. Di Cicco (2010) goes further in his conclusions and 
proposes the "public nuisance paradigm". According to this concept, media criminalize not only protesters but the idea of protest itself.

This dominant frame is a challenge for social movements: lack of media visibility reduces their capacity to influence the public agenda and the process of framing relevant issues; while their media appearance may be accompanied by a negative treatment (Armstrong et al., 2012). That is, apart from the struggle for the specific goals of the conflict, there is also another struggle: to have a proper space and a voice in mass communication, which can define the conflict's framework and its responsibilities (Cárdenas, 2014).

\section{Methodological aspects}

A qualitative content analysis was applied to a sample of news from different Spanish newspapers in their digital editions. The qualitative approach, as compared to the quantitative method, permits to better understand the object of study and to interpret and infer symbolic representations through language analysis. From Grounded Theory we took the preference for the inductive approach (Charmaz, 2008). Thus, most of the codes were created by reading and comparing the data, practicing open coding to systematize information. However, the coding process was completed with the application of additional codes derived from the theoretical framework and the state of the art. The final result is a combination of both inductive and deductive strategies (Sabariego-Puig et al., 2014). The set of codes was reviewed and grouped according to similarity into preliminary and final categories. Software Atlas.ti was used to facilitate the analysis of the sample and the extraction of results.

\subsection{Sample}

The sample of news was collected from three Spanish newspapers: El País, El Mundo and 20 Minutos. The digital edition was used for all of them. According to the Estudio General de Medios (AIMC, 2016), elpaís.com and 20minutos.es are the most visited Spanish websites in the category of general-interest media. El Mundo is the second most read print newspaper of general-interest content (the first one is El País) ${ }^{1}$. For this research we assume that the selection of news and orientation is rather similar for both the paper and the digital editions. However, the digital edition facilitates the process of collecting and analyzing data.

The period of time considered for news selection was from March 2015 to January 2016 (11 months). With this relatively wide time interval, we expected to be able to reduce the possible impact of specific phenomena and to collect information about different strikes. A quota of $2 / 3$ news articles per newspaper and per month was assigned. A final sample of 78 news articles was collected. The search engines embedded in each newspaper website were used, entering the word "huelga" ("strike" in Spanish). The most relevant news articles according to each website (based on a match with the target word) were selected to complete the expected number of news articles for each media and month. In the case of several news articles with the same relevance,

\footnotetext{
${ }^{1}$ El País belongs to the largest media conglomerate in Spain: the Prisa Group. Shareholders of the Prisa Group include the multinational telecommunications company Telefónica SA, venture capital funds and banks (HSBC, Banco Santander, Caixabank). El Mundo defines its editorial line as liberal. It is owned by Unidad Editorial SA, which is majority owned by the Italian group RCS MediaGroup. 20 Minutos is a free distribution newspaper, owned by the Spanish group Henneo, and published under a Creative Commons license.
} 
we collected the ones related to issues not previously selected, in order to include a wide range of conflicts. The objective was to achieve a qualitative non-probabilistic sample ${ }^{2}$.

\section{Results}

As a first exploratory step, headlines were analyzed, since they summarize the perspective and content that newspapers want to stress. Within the sample, the most frequent analytical codes were: "it's reported that there is a strike", "legal consequences for strikers" and "negative consequences for the non-participating population". The following quotations are examples of these $\operatorname{codes}^{3}$ : "Next Friday Renfe will be on strike: will be your train affected? (El País, 09/04/2015); "If you are travelling by plane on Saturday take the strike into account (El Mundo, 09/25/2015) and "The two people accused for the disturbances in the 29-M general strike have been absolved" (El País, 6/7/2015).

Thus, headlines frame the strikes as a problem for the non-participant population, but also for the strikers, who are at risk of being arrested. Considering this general approach, results from the analysis of the overall sample will be presented, highlighting the contents related to two main categories: the causes and the consequences of the strikes.

\subsection{Causes of the Strikes}

Sixty-four percent of the collected news articles contain references to the causes of the strikes. These references can be classified using two categories: 1) contextualized explanations and 2) immediate explanations. "Contextualized explanations" includes news articles that explain the causes from a relatively broad framework. They show a collective conception of workers and contextualize (socially, politically and economically) the specific events. These articles place the conflict within general dynamics that go beyond the concrete strike, company or working conditions in dispute. This category of news uses explanatory resources related to neoliberalism, changes in bargaining processes, workers' collective identity, other related protests, company benefits, outsourcing or offshoring processes, income inequality, and reform of labor laws. Contextualized explanations are scarce, and represent about $15 \%$ of all references to causes. The following quotes are examples of this category:

According to $C \mathrm{COO},[\ldots]$ 'the bargaining failure supposes the loss of collective rights. For instance, if a company decides to eliminate the voluntary work on Sunday or the payment of casualties, workers would have to denounce the company individually, which is currently very difficult due to the high unemployment rate and labor precariousness' (El Mundo, 23/12/2015)

This situation is caused by the outsourcing of productive processes through multiservice companies which fall outside the sector-based collective bargaining agreement, and subject the workers to conditions of absolute precariousness (20 Minutos, 04/12/2015).

\footnotetext{
${ }^{2}$ Most of the news articles in the sample refer to strikes in Spain, but strikes in other countries are also present. Hunger strikes have been excluded because they are not always related to labor, collective or social class issues. A large portion of the strikes were called by one (or two) of the majority Spanish unions: Comisiones Obreras (CCOO) and Unión General de Trabajadores (UGT). Both are class-based unions, protagonists of the worker's movement in Spain (Roca, and Sanchez, 2007). Some strikes within the sample were called by minority and/or sector-related unions.

${ }^{3}$ Quotations were originally written in Spanish. Authors have translated them into English.
} 
The second category of explanations is related to situational causes, where the immediate factors of each particular conflict are mentioned. This is the dominant category (accounting for $85 \%$ of all the news that contain references to causes). It includes news articles that explain the conflict as a unique phenomenon, without references to systemic and transversal aspects that could also affect other workers. Short comments about each specific case are included as, for example, salary reductions, deterioration of working conditions or displacements. The explanations are not framed within wider processes (such as capitalism, class struggle, surplus value, neoliberalism, etc.) nor do they pay attention to the collective, social and structural nature of conflicts. Examples of this category are expressions such as the following:

Unions are protesting the negotiation of the new collective bargaining agreement of the Public Postal Society, [...] and the staff cuts that, according to their data, have been carried out in recent years. They estimate that some 15,500 jobs have been eliminated (20 Minutos, 05/22/2015).

The workers' representatives [...] demand an end to the forced displacement of another 150 employees and advocate for the possibility for temporary employees to become permanent workers (El Mundo, 03/25/2015).

The Seat workforce has decided to resume the strike against the forced displacement of a group of workers (El País, 20/01/2016).

Approximately half of the news articles classified as immediate explanations make only a brief reference to the causes, without explaining them. For example, a protest to improve labor conditions might be mentioned, but without giving any other details about these conditions or the possible impact on workers. The following texts are examples of this type of reference:

The root of the conflict is the company's plan to change the employment conditions for new pilots, both in terms of salary scale and early retirement plans (El País, 9/9/2015)

[Unions] had called for a strike to demand better salaries and to recover their purchasing power. They assure that they have had the collective agreement frozen since January $1^{\text {st }}$ (El País, 10/14/2015).

Summing up, the structural approach is practically non-existent, and the press tends to use superficial and situational explanations or no explanation at all. The predominant frame isolates each labor conflict from its structural origin (capitalism), from its political and economic context, and sometimes even from its most immediate context (prior and related protests, the attitude of the company, acts of solidarity with the strikers, etc.) Therefore, mass media exercise as an instrument of social reproduction, accomplish a conservative function within the social system, and hinder the understanding of phenomena that could promote political, economic and social alternatives.

\subsection{Consequences of the Strikes}

Many of the headlines in the sample (around 40\%) make references to the consequences of the strikes. In particular, attention is focused on the negative consequences; the mention of positive consequences is scarce and refers to workers' partial victories or agreements. The negative consequences can consist of damage suffered by strikers (basically arrests or fines), to companies (mainly economic losses) and to the non-participating population. The following quotes are examples that refer to the first two possible affected groups:

The young people, who spent 34 days in prison, faced a sentence of eight years in jail (El País, 07/06/2015) 
Marco Antonio Estudillo, a spokesperson of employers, [...] added that the two-week strike has affected $45 \%$ of crops, and losses are estimated to be between 80 and 100 million dollars (El País, 31/03/2015)

The German company has faced eight strikes of their pilots at a cost of 232 million euros (20 Minutos, 18/03/2015).

The media do not take into account possible negative consequences that could derive from workers' dis-satisfaction, deterioration of working conditions or the economic cost that strikes imply for workers. The preference for measuring damage in terms of production and consumption (i.e., in economic terms and not in human or social terms) can be explained according to what Naredo (2013) calls the "absolute metaphor" of production. This means that production has become central to current thinking and irrefutably positive.

Finally, we can talk about a third group of affected people, the non-participating general population. Strikes appear as nuisances to everyone, as interruptions of daily life. Thus, during strikes it is possible to lose access to services such as transportation and telecommunications; access to consumption, such as the closure of shops or factories; or regular use of public spaces due to violence, damage and obstruction by protesters and pickets:

This Tuesday strikes affected about 140,000 passengers" (El País, 09/09/2015); "Protesters (...) deliberately drove slowly along the M-30, thus causing traffic jams as they move north along the road (20 Minutos, 04/10/2015)

A burning barricade due to the students' strike blocks the M-607 highway at the Autónoma [University] (20 Minutos, 03/24/2015).

\subsubsection{Formation of Opposing Sides}

The predominant frame, focused on showing negative consequences rather than structural causes, transforms strikes and other labor protests into public problems of alteration and obstruction of peaceful daily life. As a result, two opposing groups tend to be constructed: on one side there are strikers and unions, and on the other there is the rest of the population. The press seems to place their readers in the second group. Five elements can be highlighted in this process of formation of opposing sides:

- Emphasis on the negative consequences of strikes. Most of the negative consequences highlighted are suffered by companies or the non-participating population. It is even possible that a company has to pay for the damage caused to consumers by the strikes: "The operator will indemnify those customers who have suffered cuts to services as a consequence of the technicians' strike" (El País, 15/05/2015).

- Focus on strategic productive sectors. Strikes collected in the sample basically refer to strategic sectors such as transportation, communications and telecommunications, education and health: sectors that directly affect the non-participating population. The supposed interests of consumers, identified as the readers of the press, seem to be given preference in the selection of the conflicts to report on.

- Violent and war-related vocabulary: the strike as a riot. Violent vocabulary helps to create opposing sides. If there is an attack or an action that alters the daily routine, there must be someone responsible (usually the strikers), and there must be a victim (the nonparticipating population and employers). Thus, the news articles in the sample use warrelated vocabulary such as: "action plan", "threat", "union ultimatum" or "outbreak of an indefinite strike". 
- Differential representation of strikers and employers. Strikers play the role of the guilty party. They are often depicted as irresponsible, excessive, violent or noncooperative with the company. For example, "Germany has not yet recovered from the last strike, and the German engine drivers' union GDL has just announced a new one" (El Mundo, 18/5/2015). The other part of the conflict, represented by business owners, is hardly mentioned. When they are mentioned, they are shown as cooperative in searching for an agreement and as victims of the conflict: "The company, which presents itself as open to dialogue, says that the conditions applied are those stipulated by the collective bargaining agreement" (El Mundo, 30/10/2015).

- Strikers against the ideology of economic growth. This frame is consistent with the capitalist ideology of permanent growth, and with the assumption that any economic growth leads to an increase in wealth for society and in terms of general welfare (MaxNeef 2007). Production and economic growth have become an absolute metaphor, and whoever goes against them is liable to be categorized as a negative influence on society (Taibo 2011). Examples are: "The most recent strike of engine drivers alone caused losses of more than 750 million Euros, according to BayernLB. This could reduce growth by one tenth in the second trimester" (El Mundo, 18/5/2015); "Employers calculate that the cost of strike on trains is about 100 million per day" (El País, 5/19/2015). Private costs are assumed to be general costs for society.

These five elements construct a divide between strikers and non-strikers. This divide seems to indicate that employers and workers not participating in the strike have common interests. The portrayed frame is clearly unfavorable for the strikers' claims to get legitimacy and support from public opinion. Therefore, it can be concluded that the media play a conservative role that contributes to disabling social change.

\section{Discussion}

The previous sections summarize the analysis of how media frame information about strikes using a news sample from the digital editions of three major Spanish newspapers. The two main characteristics of the portrayed frame are: 1) concealment of the contradiction between capital and labor, and 2) delegitimization and isolation of strikers and labor unions. In coherence with these findings and related to a steel sector strike in the United States in 1937, Noam Chomsky (1997, p. 22) concludes:

The idea was to figure out ways to turn the public against the strikers, to present the strikers as disruptive, harmful to the public and against the common interests. The common interests are those of "us," the businessman, the worker, the housewife. That's all "us". We want to be together and have things like harmony and Americanism and working together. Then there are those bad strikers out there who are disruptive and causing trouble and breaking harmony and violating Americanism. We've got to stop them so we can all live together. The corporate executive and the guy who cleans the floors all have the same interests. We can all work together and work for Americanism in harmony, liking each other.

The strategy not only worked but it has been frequently repeated, conforming the scientific methods for strikebreaking (Chomsky, 2003). Our results are consistent with Chomsky's depiction and with previous studies about the topic. News media portray strikes through a frame that highlights damage, especially that affecting non-participating population (Winter,2007). Causes and other event-related information are presented as independent of their social and economic (capitalist) context (Morley, 1976; Thomas,2012). According to Fuchs (2009, p. 285), this is how conflicts can be "reduced to persons or other particularistic entities in order to 
forestall changing the true causes". The association of strikers and strikes with unreasonableness is easy due to the lack of relevant causal explanations (Harmon and Lee, 2010). Strikes are greedy, irrational and senseless acts (Winter, 2007). This frame also transforms activists and labor unions into social problems (Coscia, 2009; Wright, 2001; Walsh, 1988). Strikers become guilty of the conflicts against the responsible, willing to dialogue and victim position of the company and its representatives (Brennen, 2005, Harmon and Lee, 2010; Tracy, 2004).

One of the main components of the analyzed pieces of news is the account of problems that strikes cause to non-participating people. Tracy (2004) calls this predominant frame "public as victim". News media situate audiences among the affected public and consequently they are identified as consumers and not as possible members of the working class (Thomas, 2012). Martin (2004) captures this tendency with the words: "the consumer is king". This way the author refers to media's preference, when covering strikes, to not speak about worker or citizen issues (for example, labor laws), but only about interruptions in buying products and using services. This way, media favor the identification of audience members as consumers rather than as citizens or workers and accomplishes one of its main functions: favoring the "commodity circulation" (Holzer, 2017). Mass media seem to portray the most favorable agenda to capitalism by encouraging to buy and sell any commodities. Even the members of the audience become commodified when they are sold to advertisers and when they are motivated to think of themselves only as consumers (Harmon and Lee, 2010). This would configure the dominant discourse or "populist common sense" (Hall, 1983), that establishes the boundaries within which the audience can think of themselves and of labor conflicts.

Mainstream media's portrayal make it difficult for strikers to get public support (Winter, 2007). Strikes are depicted as isolated events that affect negatively, not only companies and consumers, but also the whole society. In this way, strikes are identified with economic losses, reductions in national economic competitiveness (Puette, 1992), and even with threats to the country image. This portrayal facilitates the marginalization of protests and the construction of in-group "us" (the general society affected by the protests) versus an out-group "them" (strikers and unions) (Greenberg, 2004; Knight, 2001). Mass media, in this case, contribute to the articulation (in terms of Hall or Laclau) of a national or public common interest by blurring social classes and extolling the common objectives of consumers and business owners, therefore neutralizing the potential transformative effect of workers defending their class rights.

Lazarsfeld and Merton (1974) suggested that one of the functions of mass media is to grant status to public issues and actors. That is, media help to legitimize and delegitimize certain structures and practices (Abalo, 2014). Legitimacy can be defined as the construction of something as "legally and morally acceptable" (Chouliaraki, 2005, p. 3). In this way the media intervene in the process of cultural regulation (Hall, 1997), delegitimizing strikers' behavior and supporting production. Consequently, the media seem to be spreading messages consistent with the hegemonic neoliberal ideology (Harvey, 2005), that is "the radical free market doctrine that promotes widespread deregulation, privatization, unrestricted financial/capital flows, and the erosion of organized labor as the only sustainable route to economic development" (Neubauer 2011, p. 201). Strikes and other collective actions are left out of the dominant (but contingent) discourse and acceptable behaviors, while unions and other institutions of modern state are seen as obsolete, old-fashioned and no longer necessary (Thomas, 2012; Beynon, 2003). This is how the media contribute to the capitalist project and to the projection of individualist utopias which take the individual as a consumer or a potential micro-capitalist (Holzer, 2017;Neubauer, 2011). 


\section{Conclusions}

The results obtained from the qualitative thematic analysis of a sample of news about strikes published in three major newspapers in Spain have validated the hypothesis that the media portray strikes and strikers in a negative biased way. Thus, references to the root causes of strikes are largely absent. Strikes are portrayed as isolated events that happen because of specific disagreements between companies and workers. Therefore, the root causes of the conflicts and the fundamental contradiction between labor and capital are hidden. Conflict is displaced from the capitalist system structure to the specific company and the time when each strike takes place.

The second main conclusion relates to the considerable prominence that the news articles give to the negative consequences of protests. They especially emphasize the damage caused by striking workers to non-participating population. Again, the problem is displaced from the discomfort that made the workers call for the strike to the strike itself. The conflict is no longer the structural contradiction of the private appropriation of social work, but the reaction and protest against this contradiction.

The third conclusion highlights that, as a result of the frame applied to portray the strikes, strikers and their organizations are delegitimized and therefore isolated from public opinion. This frame also hinders solidarity and empathy with workers and protests and, as a dialectical relationship, legitimizes employers and companies. In short, our analysis points to the idea that the media play a role in the reproduction and perpetuation of the capitalist system, by ignoring its structural tensions. The invisibility of the inherent contradictions of the system hinders social, political and economic alternatives.

Finally, this research has a number of limitations that must be pointed out for an accurate interpretation of results. Firstly, the sample, extracted from the three most widely read newspapers, allows relative (not statistical) representativeness, but it does not necessarily include the variety of discourses within mainstream Spanish media. For instance, some studies have observed discrepancies between different media (Thomas, 2012), which points to the necessity of further comparative research. Secondly, the criterion for selecting the units of analysis left out of the study news articles related to other issues of labor activism and unions (apart from strikes). These other aspects could have allowed us to analyze the general frame used by Spanish mainstream media to inform about the thematic field.

\section{Acknowledgments}

A brief research note with first empirical results was published in Interface: a journal for and about social movements. However, for the present article, the analysis was reworked and set within its appropriate theoretical framework.

\section{References}

Abalo, E. (2014). Constructing (il)legitimate democracy: populism and power concentration in newspaper discourse on Venezuela, Triple C, 12 (2), 802-821. Accessed June 10, 2018. http://www.triple-c.at/index.php/tripleC/article/view/572

AIMC. (2016). Estudio General de Medios: Febrero 2016 a Noviembre 2016. Madrid: AIMC. Accessed March 16, 2017. http://www.aimc.es/ 
Armstrong, C.L., Boyle, 1. P. and McLeod, D.M. (2012). A Global trend. ,Journalism Studies, 13 (4), 633-648. DOI: 10.1080/1461670X.2011.616404.

Beynon, H. (2003). Globalization, trade union organization, and workers' rights. In P. Fairbrother and C.A.B. Yates (Eds). Trade unions in renewal: a comparative study. London, UK: Routledge, 263-281.

Brennen, B. (2005). Lockouts, protests, and scabs: a critical assessment of the Los Angeles Herald Examiner strike. Critical Studies in Media Communication, 22(1), 64-81. DOI: 10.1080/0739318042000317309.

Brimeyer, T., Silva, E.O. and Byrne, R.J. (2016). What do unions do? Media framing of the two-faces of labor. Working USA, 19, 517-532. DOI: 10.1111/wusa.12259.

Bruno, R. (2009). Evidence of bias in the Chicago Tribune coverage of organized labor. Labor Studies Journal, 34 (3), 385-407. DOI: 10.1177/0160449X08319949.

Cárdenas, J.D. (2014). ¿El tal paro agrario nacional no existe? Análisis del cubrimiento mediático y las rutinas de comunicación política en las movilizaciones campesinas en Colombia. Temas de Comunicación, 28, 55-77. Accessed July 18, 2017. http://revistasenlinea.saber.ucab.edu.ve/temas/index.php/temas/article/view/2150/2110

Carreiro, J. (2005). Newspaper coverage of the UD Labor movement: the case of anti-union firings. Labor Studies Journal, 30 (3), 1-20. DOI: 10.1177/0160449X0503000301.

Charmaz, K. (2008). Grounded Theory as an emergent method. In S. N. Hesse-Biber and L. Patricia (Eds.), Handbook of emergent methods. New York: Guilford Press, 157-172.

Chouliaraki, L. (2005). Introduction: the soft power of war. Legitimacy and community in Iraq war discourses. Journal of Language and Politics, 4 (1), 1-10. DOI:10.1075/bct.3.02cho.

Chomsky, N. (1997). Media control. the spectacular achievements of propaganda. New York: Seven Stories Press.

Chomsky, N. (2003). Chomsky on democracy and education. London and New York: Routledge Farmer.

Clarke, J. (2015). Stuart Hall and the theory and practice of articulation. Discourse: Studies in the Cultural Politics of Education, 36 (2), 275-286. DOI:10.1080/01596306.2015.1013247.

Corner, J. (2001). 'Ideology': a note on conceptual salvage. Media, Culture \& Society, 23 (4), 525-533.

Coscia, V. (2009). La prensa gráfica y sus mecanismos de deslegitimación: un análisis de dos huelgas antes y después del auge neoliberal en argentina. Diálogos de la Comunicación, 78, 1-8. Accessed June 11, 2018. https://dialnet.unirioja.es/servlet/articulo?codigo=3719830

Di Cicco, D. T. (2010). The public nuisance paradigm: changes in mass media coverage of political protest since the 1960s. Journalism and Mass Communication Quarterly, 87 (1), 135-153. DOI: $10.1177 / 107769901008700108$.

Donoghue, M. (2017). Beyond hegemony: elaborating on the use of Gramscian concepts in critical discourse analysis for political studies. Political Studies. Online First. DOI: $10.1177 / 0032321717722362$.

Entman, R. M. (1993). Framing: toward clarification of a fractured paradigm. Journal of communication, 43 (4), 51-58. DOI: 10.1111/j.1460-2466.1993.tb01304.x. 
Erickson, C. and Mitchell, D. (1996). Information on strikes and union settlements: patterns of coverage in a 'Newspaper of Record'. Industrial and Labor Relations Review, 49(3), 395407. DOI: $10.2307 / 2524193$.

Farooq A. K. (2015). Marxist theory of the media or theory of the media by Marxists? Reconciling Adorno with other Marxist media theorists. Journal of Communications Media Studies, 7, 61-78.

Fuchs, C. (2009). Towards a Critical Theory of Information. Triple C, 7(2), 243-292. Accessed June 11, 2018. http://www.triple-c.at/index.php/tripleC/article/viewFile/91/131

Goldman, R. and Rajagopal, A. (1991). Mapping hegemony: television news coverage of industrial conflict. Norwood, NJ: Ablex.

Gramsci, A. (1971). Selections from the Prison Notebooks. New York: International Publishers.

Greenberg, J. (2004). Tories, teachers, and the media politics of education reform: news discourse and the 1997 Ontario teachers' strike. Journalism Studies, 5(3), 353-371. DOI:10.1080/1461670042000246106.

Hall, S. (1983). The problem of ideology. Marxism without guarantees. In B. Matthews (Ed.) Marx: 100 years on. London: Lawrence \& Wishart, 28-44.

Hall, S. (1988). The toad in the garden: Thatcherism among the theorists. In C. Nelson and L. Grossberg, Marxism and the interpretation of culture. Chicago: University of Illinois Press, $35-57$.

Hall, S. (1997). The centrality of culture: notes of the cultural revolutions of our time. In K. Thompson (Ed.), Media and cultural regulation. London, Thousand Oaks \& New Delhi: SAGE, 207-238.

Harmon, M. D. and Lee, S. (2010). A longitudinal study of U.S. network TV newscasts and strikes: political economy on the picket line. Journalism \& Mass Communication Quarterly, 87 (3/4), 501-514. Accessed June 11, 2018. http://trace.tennessee.edu/utk_jourpubs/3

Harvey, D. (2005). A brief history of neoliberalism. Oxford: Oxford University Press.

Holzer, H. (2017). The 'forgotten' Marxist theory of communication \& society. Triple C,15 (2), 707-725. Accessed June 11, 2018. http://www.triple-c.at/index.php/tripleC/article/view/908/0

Knight, G. (2001). Prospective news: press pre-framing of the 1996 Ontario public service strike. Journalism Studies, 2(1), 73-91. DOI: 10.1080/14616700120021801

Kumar, D. (2001). Mass media, class, and democracy: The struggle over newspaper representation of the UPS strike. Critical Studies in Media Communication, 18 (3), 285-302. DOI: $10.1080 / 07393180128086$.

Lazarsfeld, P. and Merton, R. (1974). Los medios de comunicación de masas, el gusto popular y la acción social organizada. In D. Bell et al., Industria cultural y sociedad de masas. Caracas: Monte Ávila Editores, 231-259.

López, A. (2014). El populismo como lógica hegemónica: una mirada a la perspectiva teórica elaborada por Ernesto Laclau. Hallazgos, 11 (22), 245-262. DOI: 10.15332/s17943841.2014.0022.13.

Martin, C. R. (2004). Framed! Labor and the corporate media. Ithaca, NY: ILR Press, a Cornell University Press.

Marx, K. (1932/1984). Manuscritos: economía y filosofía. Madrid: Alianza Editorial. 
Marx, K. and Engels, F. (1846/1970). The German ideology. London: Lawrence \& Wishart.

Max-Neef, M. (2007). La dimensión perdida. La deshumanización del gigantismo. Barcelona: Icaria Editorial S. A.

McChesney, R. W. (1999). Rich media, poor democracy: communication politics in dubious times. Urbana, IL: University of Illinois Press.

McCurdy, P. (2012). Social movements, protest and mainstream media. Sociology Compass, 6 (3), 244-255. DOI: 10.1111/j.1751-9020.2011.00448

McLeod, D. and Detenber, B. (1999). Framing effects of television news coverage of social protest. Journal of Communication, 49 (3), 3-23. DOI: 10.1111/j.1460-2466.1999.tb02802.x.

Mills, C. W. (1960). La élite del poder. México: F.C.E.

Morley, D. (1976). Industrial conflict and the mass media. The Sociological Review, 24 (2), 245-268. DOI: 10.1111/j.1467-954X.1976.tb00112.x.

Naredo, J. M. (2013). Ideología político-económica dominante y claves para un nuevo paradigma. Revista de Economía Crítica, 16, 108-143. Accessed June 11, 2018. http://revistaeconomiacritica.org/sites/default/files/revistas/n16/03_JoseManuelNaredo.pdf

Neubauer, R. (2011). Neoliberalism in the information age, or vice versa? Global citizenship, technology, and hegemonic ideology. Triple C, 9 (2), 195-230. Accessed June 11, 2018. http://www.triple-c.at/index.php/tripleC/article/view/238

Oshagan, H. and Martin, C. (1999). Coverage of labor and management in the willow run assembly plant shutdown. Labor Studies Journal, 23 (4), 17-33. DOI: 10.1177/0160449X9902300402.

O’Sullivan, T., Hartley, J., Saunders, D., Montgomery, M. and Fiske, J. (1994). Key Concepts in Communication and Cultural Studies. London and New York: Routledge.

Parenti, M. (1993). Inventing reality: the politics of news media reality. New York: St. Martin's Press.

Puette, W. J. (1992). Through jaundiced eyes: how the media view organized labor. Ithaca, NY: ILR Press.

Roca, B. and Sánchez, R. (2017). Adversarios del sindicalismo. Un análisis del discurso antisindical en el diario español la Razón. Athenea Digital, 17 (3), 3-28. DOI: 10.5565/rev/athenea.1506.

Sabariego-Puig, M., Vilà-Baños, R. and Sandín-Esteban, M.P. (2014). El Análisis Cualitativo de Datos con ATLAS.ti. REIRE, 7(2), 119-133. Accessed June 11, 2018. https://www.researchgate.net/publication/263859187_El_analisis_cualitativo_de_datos_con_ ATLAS ti

Slack, J. (1996). The theory and method of articulation in Cultural Studies. In S. Hall (Ed.) Critic dialogues in Cultural Studies. London: Routledge, 112-127.

Taibo, C. (2011). El decrecimiento explicado con sencillez. Madrid: Catarata.

Thomas, R.J. (2012). Dinosaurs and donkeys: British tabloid newspapers and trade unions, 2002-2010. PhD Dissertation. Washington State University. Accessed August 7, 2017. https://research.libraries.wsu.edu/xmlui/handle/2376/4086?show=full

Tracy, J. (2004). The news about the newsworkers: press coverage of the 1965 American 
newspaper guild strike against the New York Times. Journalism Studies, 5 (4), 451-67. DOI: 10.1080/14616700412331296392.

Van Dijk, T. (2002). El análisis crítico del discurso y el pensamiento social. Athenea Digital, 1, 18-24. DOI: $10.5565 / \mathrm{rev} / \mathrm{athenead} / \mathrm{v} 1 \mathrm{n} 1.22$.

Walsh, G. (1988). Los sindicatos y los medios de comunicación social. Revista Internacional del Trabajo, $107 \quad$ (3), 70-87. Accessed June 11, 2018. http://gumilla.org/biblioteca/bases/biblo/texto/COM198965-66_70-87.pdf

Williams, R. (1977). Marxism and literature. Oxford: Oxford University Press.

Winter, J. (2007). Lies the Media tell us. New York: Black Rose Books.

Wood, B. (1998). Stuart Hall's Cultural Studies and the problem of hegemony. The British Journal of Sociology, 49 (3), 399-414.

Wright, B. J. (2001). Managing dissent: the mass media and American labor unions. South Dakota State University. Accessed June 11, 2018. https://search.proquest.com/central/docview/276309182/fulltextPDF/9A5D28F2A7D74F43P Q/1? accountid=17192 